\title{
Recollection of the Historical Portuguese Orchid Collection from 1879
}

\author{
Pekka Ranta \\ Orchid Garden, Janhuan Orkidearanta Oy, Sulkava, Finland
}

Email address:

pekkaranta3@gmail.com

\section{To cite this article:}

Pekka Ranta. Recollection of the Historical Portuguese Orchid Collection from 1879. International Journal of Science, Technology and Society. Vol. 7, No. 4, 2019, pp. 56-60. doi: 10.11648/j.ijsts.20190704.11

Received: June 27, 2019; Accepted: August 29, 2019; Published: September 12, 2019

\begin{abstract}
A new orchid house was built before 1879 in Portugal (Ajuda, Lisboa) for the orchid collection of the King Luis I of Portugal. That house was designed using the best technical solutions of that time. The orchid collection of 438 different orchids, almost all of which were natural species was clearly larger than most collections in botanic gardens in Europe and other non tropical areas then and today. After the Lisbon Regicide, the murder of King Carlos I of Portugal, the follower of King Luis I, the Botanic Garden of Ajuda including the orchid collection was transferred from The Royal administration to the University of agriculture and the collection started to decline and disappeared completely. A private family (Tuulikki and Pekka Ranta), who transported their collection of about 10000 orchids from Finland to Portugal (2011) has decided and promised to recollect that historical orchid collection in such a way, that the collection can be visited and studied a reasonable long time in the future. The recollection is planned to be completed during 2021, 140 years after the complete list of the orchid collection of King Luis I was signed.
\end{abstract}

Keywords: Historical Plant Collection, Orchids, Taxonomy, Natural History, Species, Hybrids, Botanic Garden, History, Lisbon, Portugal

\section{Introduction}

When we look back 300 years - orchids and Europe had totally different relation than they have today. Sailboats from Smyrna (today Izmir in Turkey) dropped to British ports and from them barrels of orchid powder was unloaded to produce a hot drink (salep) for London's cold-nosed street walkers. Then the flowering red meadows were destroyed because armies needed horses and horses needed hay. The meadows from Europe to Turkey and even to Belutšistan were fertilized - the orchids lost the fight.

This all was changed about 1818 when orchids from tropics entered the stage. It was just one plant (it got the name Cattleya labiata) and many persons reacted like during the gold rush.

King Luis I of Portugal started to collect orchids during the time when the greatest eager to get orchids from tropics was already over (1870s) For some previous decades the situation was described by the following words: "Thus hundreds of beautiful species, which had been collected at great cost and risk, and were purchased by eager amateurs at home, oftentimes at high prices, rapidly died out, simply from the prevailing ignorance of the climatal conditions of the localities in which they had been collected. [1]

At the same period some of the great names of biology, important for knowledge of orchids, had passed away or came to the end of their scientific life (Charles Darwin (1809 - 1882), John Lindley (1799 - 1865), H. G. Reichenbach (1823 - 1889) And some of the most important professional companies to grow and sell orchids just started to get form (Sander bought the place in St. Albans 1881)

'Jardim Botanico da Ajuda', the oldest botanic garden of Portugal was in quite bad shape about 1870, so the Royal administration took it over and started work to renovate the garden. 'Jardim Botanico' is located just "over the street" from the Royal Palace. Orchid house was one part of the renovation work.

When we compare the Orchid collection of King Luis I with orchid collections of all Botanic Gardens in Portugal the result is amazing. The situation 1.1.2016 was such that all Botanic Gardens had totally about same amount of orchids in their collections as the King Luis I had 140 years ago. Of 
those modern collections clearly more than $50 \%$ of the orchids are hybrids. Different orchid species they had less than $30 \%$ of the amount that the King Luis I had. All is not better today.

\section{The New Orchid House 1879}

The new orchid house in 'Jardim Botanico da Ajuda' was designed keeping in mind the problems of earlier orchid houses around Europe. The floor was about one meter under the level of surrounding ground, it has also ventilation tubes in the walls. That tried to keep the temperature during summer lower than in older greenhouses. For the cold nights in winter there was heating system using warm water in four tubes along the walls. So it was a modern orchid house at its time. The house was 25 meters long, 5,5 meters wide. The house was filled by orchids so that 1879 there was about 260 orchids and 1881 there was about 440 orhids.

That greenhouse is still in the Ajuda botanic garden. When we moved most of our orchids from Coimbra to Ajuda, we placed in this house about 1200 orchids. The house is not anymore like it was hundred years ago. There has been a renovation of the house 2005. After that there is not heating or cooling and the ventilation has been lost too.

\section{The Orchid Collection}

There are two printed catalogues about the orchids in the collection of King Luis I.

The first catalogue from 1879 signed by Luis de Mello Breyner in 'Jardim Real do Paco d'Ajuda' on December 1879.

It has totally 285 orchids listed.

The second catalogue from 1881 signed by Luis de Mello Breyner in 'Jardim Real do Paco d'Ajuda' on October 1881.

It has totally 438 orchids listed, species or natural hybrids and even two man made hybrids.

Something has happened during the time between the catalogues. Totally 25 species from the first list are not any more in the second list.

\subsection{Hybrids}

Man made orchid hybrids caused first time a sensation when they were displayed about 1885 - 1890. But they were made long time before that. The time from pollination to the first flowers could take 15 years with the methods used at that time. One of the first hybrids, Selenipedium dominianum an English hybrid between Selenipedium Pearcei and caudatum was already in the first list of the collection.

In the second list there was also"... Cattleya Veitchiana, Patria?..., That means that it is unknown who has defined the plant name and it is not known where it is growing.

Today this plant is considered as Cattleya $\times$ veitchiana Dominy 1874 - unplaced (Kew).

Cattleya crispa $(1828) \times$ Cattleya labiata (1824)

Mello Breyner do not mention, that this plant is a hybrid, but it comes from the same nursery as the previous hybrid Selenipedium dominianum.
Today this plant is considered as Phragmipedium Dominianum Veitch 1870 - registered (RHS).

Phragmipedium caricinum (1896) × Phragmipedium caudatum (1896)

John Dominy $(1816$ - 1891) was a British plant hybridiser. He worked at the Veitch Nurseries. He did several of the first orchid hybrids.

It is easy to find today a Phragmipedium Dominianum to add to our recollected collection. Cattleya $\times$ veitchiana is probably not possible. Maybe we have to make it from our Cattleya crispa and Cattleya labiata.

There are some natural hybrids also in the collection. These will be treated as normal species.

\subsection{One Species with Two Names}

There are several cases where two or three different names in the old lists are today considered as one species.

To start with Cattleya,

List -79 Laelia Perrini, Lindl. Brasil

List -79 Cattleya Perrini, Lindl. Brasil

List -81 Laelia perrini, Bateman. Brasil

List -81 Cattleya Perrini, Lindl. Brasil

Today this orchid is Cattleya perrinii Lindl. 1838 and it is found in Brasil.

Then we have

List -79 Aerides arachnitis, Sw. Japao

List -81 Aerides arachnitis, Sw. Japao

List -81 Renanthera arachnites, Lindl. Japao

Today those both are Arachnis flos-aeris (L.) Rchb. f. 1886.

Carl von Linné has named this plant already 1753 as Epidendrum flos-aeris.

The next "couple"

List -79 Goodyera discolor, Kerr. Brasil

List -81 Goodyera discolor, Kerr. Brasil

List -81 Anoectochilus Dawsoni, Patria?

Today Ludisia discolor (Kerr Gawl) A. Rich. Southeast Asia.

List -79 and List 81 Dendrobium nobile, Lindl. Ind. China

List -79 and List 81 Dendrobium coerulescens, Wall. Ind. Or.

Today Dendrobium nobile Lindley 1830. Is found in large area from India and China to Thailand and Vietnam.

Then comes

List -79 Angraecum superbum, D-P-T. Madagascar

List -81 Angraecum eburneum, D-P-T. Madagascar

List -81 Angraecum superbum, D-P-T. Madagascar

List -81 Angraecum virens, Patria?

Today those two last seems to be

Angraecum eburneum subsp. Superbum (Thouars) H. Perrier

And the Bulbophyllum

List -79 and List -81 Bolpophyllum Henshalli. Lindl. Asia. Africa

List -79 and List -81 Bolpophyllum siamense. Reich. Siao

Today those seem to be Bulbophyllum lobbii Lindley 1847 and is found growing in Borneo, Indonesia, Malaysia, and the Philippines. 
The total amount of 438 different orchids will actually be less than 420 when all those "double names" has been cleared.

There is a special difference between those two lists. In the older list (List -79) there is 18 orchids where the origin is in form "Patria?". So the growing place is unknown. Of those

The rest of them:

Masdevallia Bomplandi. Rchb. f.

Masdevallia Civilis. Rchb. f.

Masdevallia Coreacea (today coriacea). Lindl.

Masdevallia Davisii. Rchb. f.

Masdevallia Macure. Rchb. f.

Masdevallia Ochtodes. Rchb. f.

Masdevallia Peristeria. Rchb. f.

Masdevallia Bella. Rchb. f.

Masdevallia Hypodisa (today hypodiscus). Rchb. f.

These all come from high altitudes, even up to $3500 \mathrm{~m}$. The orchid house in Ajuda was too hot for them.

In the second list (List -81) there are 95 orchids with unknown origin and most of them also no information about who has given the name. Between those two years the garden has got at least 170 new orchids. Half of them with less information than the previous orchids had. In this unknown group are most of the orchids that will be difficult to find. Names as Trichopilia sp nova, Catasetum sp nova, Oncidium sp d'Australia belong to the most difficult to find, if not impossible.

\subsection{Just New Names}

One of the difficult and interesting species in the historical orchid collection has name Cypripedium Crossii. In todays "world of orchids" there is discussion going on about this species.

The footprints in history are about these: 1865 there was a picture in 'La Belgique Horticole' by E. Morren showing Cypripedium crossii without any description of the plant. Later, 1883 there was even a description of that species in the same journal (E. Morren was the editor of that journal and the Director of 'Jardin botanique de l'Université de Liège' He died 1886).

Reichenbach gave name Cypripedium callosum 1886 to a plant that looks like this Cyp. Crossii. Later these Cypripediums has been moved to Paphiopedilum. [2]

The discussion goes approx. so that there are persons who say that the Cyp. crossii has just disappered from our world, which makes Cyp callosum to a new totally different plant. Then there are other persons who say that the correct name for this previous Cyp. crossii is today Paphiopedilum barbatum. All this discussion is hard to make fit with the old lists of the orchid collection of King Luis I of Portugal.

In the older list (1879) there is Cypripedium barbatum and three variations of Cyp. barbatum by Lindley, coming from Malaga and India. There is no Cyp. Crossii.

In the second list (1881) there are still all those Cyp. barbatums but now also "... Cypripedium Crossii. Plan. et
18 totally 11 are Masdevallias and they all died before 1881 . Those Masdevallias had no information who gave the names. Today these Masdevallias are easy to identify. First two of them, M. Benedicti and M. Troglodytes are today Dracula benedictii (Rchb. f.) Luer 1978, found in Colombia $2000 \mathrm{~m}$ over sea level.

1855 Col, Peru
1854 Col, Peru
1845 Col, Peru
1874 Peru
1874 Col, Peru
1855 Col, Peru
1874 Col, Ecu
1874 Col, Peru (today Dracula bella)
1878 Col, Peru

Brong. Patria? (")... "So... at that time barbatum and crossii were different species. Cyp. crossii was not connected to E. Morren, instead there seems to be Adolphe Theodore Brongniart behind the definition. And that definition has happened latest 1876 because professor Brongniart died then.

I have not found Brongniart in any data bases handling Cypripedium crossii or Paphiopedilum callosum. Brogniart was professor in "Museum d'Histoire Naturelle, Paris" and was one of the most prominent botanists at that time. [3]

My real problem is easy to solve. I shall collect an orchid sold as Paph. callosum and control that the flowers look like the old painting shown by E. Morren looks like. (The offical name of that plant will in future be Paphiopedilum crossii)

Other difficulties as example:

Oncidium spec. De Santa Catherina - not totally impossible.

Oncidium sp. D'Australia.

Cattleya Lindleyana. Mont de Orgues [4].

Pleurothallis spec?

Lusophia lurida. Patria? - is this an orchid or just something else?

"Cattleya Russeliana. Patria?" Is an interesting detail in the second list (1881) As I went through the databases available 2015 when the work to recollect started there was nothing to find. Only once mentioned in a letter to Darwin.

Now the situation is different. Plant list and Orchid Roots tell that Cattleya $\mathrm{x}$ Russeliana is a hybrid registered by Mantin 1897 and it is synonym to Cattleya $x$ whitei Rchb. $f$. 1882. I have not found that hybrid in the Sander's list of orchid hybrids. [5]

I feel a bit astonished. The garden of Ajuda has got Cattleya Russeliana 1881 or the previous year. Reichenbach identifies it the next year (1882) but gives a new name and then Mantin has got it to open flowers to be registered again as Cattleya $\mathrm{x}$ russeliana 1897. The first question is who sold the plant with Russeliana-name to Portugal and why he lost the rights to that name?

The same plant was under discussion during the Third International Conference 1906 on Genetics: Hybridisation... 
According conversation Mr. White found the plant growing in a tree in company with $\mathrm{C}$. Labiata and $\mathrm{C}$. Schilleriana - those were then suspected as parents.

Later $\mathrm{Mr}$ Boxall told that the other parent was not $\mathrm{C}$. Labiata but $\mathrm{C}$. Warneri in that tree. The parents of the hybrid that afterwards was raised artifically were C. Warneri and C. Schilleriana. [6]

This plant has been identified 1836 as Cattleya guttata var. russelliana Hook.

So we have a small problem. How should the plant look like in the new recollected orchid collection?

The amount of new easy to find names for the orchids in the second list is about 170 (of 438) and the amount of not possible to find from known databases or from known supppliers of orchids when we started this work 2015 was 80 names. [7-10]

Some features of the species in the catalogues: There are 46 different Cattleyas plus 14 Laelias (of which today 6 are Cattleyas). Inside these Cattleyas, Cattleya mossiae has 9 different variations. The problems with names are result of the fact that about $50 \%$ of the names in the lists are not valid any more.

Quite popular has been also Odontoglossum with 36 species and Oncidium with 49 species.

Orchids in those catalogues came from different continents with South America as the main source. This is easy to understand from the history of Portugal. From Europe 7\% and from Africa $2 \%$

\subsection{The Dark Years}

The King Carlos I of Portugal was murdered 1.2. 1908 in Lissabon. After that the Botanic garden of Ajuda was transferred from the Royal administration to the University of agriculture. The orchid collection followed Then the collection started to slowly decline until it disappeared. Some eyewitness says that at least one species was left about ten years ago.

I do not know anything what happened to this collection during and after the revolution - anyway nobody has told that he or she knows where one or more of these plants are today. When we came to Portugal there was in all official collections only small amounts of orchids, mostly in not so good shape. Are some of the orchids in those official collections originally from the collection that was in Ajuda?

\section{New Start}

Our family came to Portugal 2011 with about 10000 orchids - our collection. Our idea was that we may find here an organisation (Botanic Garden) that could be interested to accept as donation the collection because we believed that some day we may be too old to take care of it. We have not yet found what we were looking. [11, 12]

When we were "located in Coimbra" we were informed about the historical collection of King Luis I and the fact that nobody was trying to recollect it - there had been discussions but no results.
We decided to try to do the job.

At this moment we are planning to celebrate the recollection of almost the whole collection during 2021.

The "King's Orchid Collection" is only 5\% of our family's orchid collection, so this is not a particularly ambitious project for us when we think about the volymes. [13-17] The other part of the work is then more ambitious. How to find all the species that are written in the historical catalogues

When we are now making a replica of that historical orchid collection, we are handling problems of different kind. First we must identify the orchid species, natural hybrids and a few man made hybrids that made the collection. Less than $50 \%$ of those orchids have today the same name as they had 1881. We must follow the chain of new namings made by new generations of botanists. But that is not enough. In some cases it seems that a description of an orchid flower written 140 years ago is different from what the corresponding name gives today. So we must also try to find orchids that look like the old descriptions - no matter what the name is today.

The second problem is to find and buy those orchids. Lucky for us we already have in our family collection about 250 orchid species and natural hybrids that quite possibly are plants that are in those old lists from 1879 and 1881. To find an buy the rest will take one or two years.

But then comes a problem of totally different kind. The historical collection has once disappeared, after the revolution. It can disappear again. The other problem of this kind is the slow dying of plants. Situation today is not as bad as it was 1830 s or 1850 s. But even today we can record the rate of species deaths in public collections at levels $5 \ldots 10 \%$ per year.

This can be kept under control only with correct facilities and with persons with proper qualities. This part of the work is at this moment quite fragile. How many botanic gardens have courage to boast that they have all that is needed to start to take care of an orchid collection of 1000 orchids. And to have the collection in good shape after 10 or 20 years.

\subsection{The New Orchid House}

We know now the quality and quantity of the greenhouses in Portuguase botanic gardens. It is not possible to think to place the recollected historical orchid collection to any of them. That is why we started during autumn 2016 to build a pilot greenhouse in the Porto region inside a private botanic garden. That greenhouse has the same shape as the old orchid house in Ajuda and the total size is $50 \%$ of that old greenhouse. We did it to test how orchids can be grown in a proper way in those circumstances. Now we have two years growing experience of that house as an orchid house. The growth and flowering of orchids in that house are superior to all greenhouses we have experienced in Portuguese botanic gardens.

Based on this pilot we know now what kind of greenhouse we have to build for the recollected historical orchid collection. The dimensions and the walls will be the same as in the old house in Ajuda. The house will be built directly on the ground - cooling will be achieved with other 
methods than digging the house down. Materials in the new house will be different but look the same as in the old. Devices needed for the plants will be such that we use in all our orchid houses. That new house should be ready on October 2021.

\subsection{Extra Work in Buying Species}

Practical work to buy orchid species that are mentioned in those catalogues has shown that even good quality orchid centers send to us orchids of which one third is not what the name label tells. The reason for this may be that the species we are looking for are very rare in today's trade. Most orchid specialists do not recognize these.

\section{Conclusion}

An orchid house was built 1879 for the orchid collection of King Luis I of Portugal. His collection had 430 different orchid species. The greenhouse was condidered as innovative.

After revolution 1910 the orchid collection started to decline until it disappeared totally.

From 2015 a Finnish family has been working to recollect that historical orchid collection. The recollection work has been planned to be completed during 2021 .

\section{References}

[1] Williams, B. Williams, H (1894). The orchid-grower's Manual, Victoria and Paradise Nurseries, London, England.

[2] Braem, G \& Senghas, K. (2000), 'THE INTRIGUING CASE OF CYPRIPEDIUM CROSSII, ITS PRIORITY OVER CYPRIPEDIUM CALLOSUM AND ITS TRANSFER TO THE GENUS PAPHIOPEDILUM, SIDA, Contributions to Botany, Vol. 19, No. 2, pp. 249-255.

[3] The Roots of Paleobotany: Brongniart and Fossil Plants. https://blog.biodiversitylibrary.org/2015/10/the-roots-ofpaleobotany-brongniart-and-fossil-plants.html.
[4] Lindley, J. (1852), Folia Orchidacea, J Matthews. London, England.

[5] Sanders, D. (1961) Orchid hybrids, One-table list of orchid hybrids, David Sander's orchids Ltd, Leicester. England.

[6] Wiks, W. (1906) Report of the Third International Conference 1906 on Genetics: Hybridisation ... p 224. https://www.biodiversitylibrary.org/bibliography/118849\#/su mmary.

[7] Lindley, J. (1830), Orchidaceous Plants, Ridgways. London, England.

[8] Curtis's Botanical Magazine (1858) vol. 84 (Ser. 3 no. 14) Table 5035. Wiley Online Library.

[9] Curtis's Botanical Magazine (1858) vol. 84 (Ser. 3 no. 14) Table 5048. Wiley Online Library.

[10] Curtis's Botanical Magazine (1858) vol. 84 (Ser. 3 no. 14) Table 5072. Wiley Online Library.

[11] Casal finlandês mudou-se para Viana do Castelo com 10 mil orquideas. PT Noticias https://www.rtp.pt/noticias/pais/casalfinlandes-mudou-se-para-viana-do-castelo-com-10-milorquideas_v522197.

[12] Finlandeses dão 10 mil orquídeas a Coimbra - Portugal. CMjornal https:/www.cmjornal.pt/portugal/detalhe/finlandesesdao-10-mil-orquideas-a-coimbra.

[13] Ranta, P. (2008). Kulttuuriorkideat, Janhuan Orkidearanta Oy, Loimaa, Finland.

[14] Ranta, P. (2006). Aito Orkideakirja, part 1. Janhuan Orkidearanta Oy, Tallin, Estland.

[15] Ranta, P. (2005). Kukkiva kaunotar - Phalaenopsis. Janhuan Orkidearanta Oy, Loimaa, Finland.

[16] Ranta, P. (2003, 2007). Orkideat koti-ikkunalla. Janhuan Orkidearanta Oy, Loimaa, Finland.

[17] Ranta, P. (2000). Orkideat Kotosalla. Janhuan Orkidearanta Oy, Loimaa, Finland. 